\title{
Study on the Development and Driving Factors of Inbound and Outbound Tourism between China and Russia in the Last 15 Years*
}

\author{
Wen Pang \\ Tourism and Research Institute of Human Geography \\ Xi'an International Studies University \\ Xi'an, China
}

\begin{abstract}
This paper selects the statistical data of the last 15 years to conduct a comparatively comprehensive analysis of the relationship between the size of the outbound tourism market in China and Russia, the interrelationship between the inbound and outbound passenger flow and import and export trade, and the impact of major events on tourism. The results showed that: The passenger flow volume of outbound tourists of China to Russian as a whole shows an upward trend, which is divided into two stages of gentle growth and rapid growth with 2013 as the boundary; the passenger flow volume of outbound tourists of Russia to China as a whole shows an upward trend and then a downward trend, which is divided into two stages of stable growth and fluctuations fall with 2009 as the boundary. The major events such as the global economic crisis in 2008 have a greater impact on Russia's outbound tourism to China. There is a strong correlation between outbound tourism of Russia to China and service trade exports, and there is a strong correlation between China's outbound tourism to Russia and the export and import of service trade between the two countries.
\end{abstract}

Keywords-Sino-Russia tourism; background trend line; correlation analysis

\section{INTRODUCTION}

As a sustainable development industry, the tourism industry has been developing rapidly around the world and is also an important growth point for the national economy of China and Russia. China and Russia are neighboring countries, and their land area and economic volume are at the forefront of the world. Two-way tourism interaction has important significance for the peoples of the two countries to promote friendship and enhancement of strategic partnership between the two countries. It has also received extensive attention from academic circles at home and abroad. Wang Jiejie and Sun Gennian study the influence of international relations and major events on the inbound and outbound tourism [1]. Wang Wenyi studies the influence of the

*Fund Project: Special Research Project of the Department of Education of Shaanxi Province "Study on the Composition, Measurement and Development Model of Social Capital in Tourist Destinations: Taking China's Inbound Tourism as an Example" (17JK062) The research fund project of Xi'an International Studies University, "Research on Sustainable Development Index of countries along "Belt and Road"(2018XWD01).

\author{
Yu Zhang \\ Tourism and Research Institute of Human Geography \\ Xi'an International Studies University \\ Xi'an, China
}

political and economic development of China and Russia on the tourism of the two countries [2]. Cheng Bing and Zhu Jinsheng study the influencing factors of the consumer behavior of Russian tourists' in China [3]. Victoria and Cui Weihua study the strategy of China and Russia developing international tourism cooperation [4]. Song Kui and Chen Qiujie reviewed and looked forward to tourism cooperation between China and Russia [5]. Shi Zhangyu conducts an empirical study on the interactive relationship between bilateral tourism and import and export trade between China and Russia [6]. Ovcharov (2008) systematically studies the risks of the Russian tourism market. [7] Peter Burns studies the issue of tourism development in the transition process of socialist system from the Soviet social system to capitalism in Russia [8]. However, the pre-researches are mainly concentrated in the years before 2009 and the researches on Sino-Russian tourism in the past 10 years are relatively few. Since 2009, the bilateral trade volume between the two countries has continued to grow and the two sides have established a comprehensive strategic partnership, resulting in great changes in the background of tourism development. Some studies of scholars use the outbound data from areas such as Manchuria instead of China's total outbound passenger flow data. This paper uses China's total outbound passenger flow as the basis for analysis, and sorts out the development of tourism between China and Russia since 2001, to make up for the gap in bilateral tourism research between China and Russia at the time.

\section{DATA SOURCES AND RESEARCH METHODS}

This article selects the Sino-Russian outbound tourism data from 2001-2016 and the import and export data of SinoRussian services trade for study. The data comes from the "Russian Central Bank", "China Statistical Yearbook" and "BRICs Statistics Handbook." The use of SPSS software to conduct relevant research on the data, mainly answers the following three questions: the changes in passenger flow in China and Russia, the impact of major events on bilateral tourism, and the correlation between the inbound and outbound passenger flow volume and the import and export of service trade. 


\section{CHINESE OUTBOUND TOURISM TO RUSSIA}

\section{A. The Changes in the Passenger Flow Volume of Chinese Outbound Tourists to Russia}

The growth of passenger flow volume is the first indicator of tourism development. "Fig. 1" shows the change of passenger flow of China Outbound Russia Tourist during 2001-2016. It shows the cubic function growth trend. The dotted full line is the statistics line of passenger flow volume, and the line without dot is the background trend line of tourism. The overall flow volume of passengers from China outbound Russia is on the rise. The total amount has increased from 156,792 in 2001 to $1,288,720$ in 2016, an increase of 8.22 times. It can be broadly divided into two phases: gentle growth period and rapid growth period. From 2001 to 2013, it is a period of moderate growth. The total passenger flow slowly increased from 156,792 people to 372,314 , with an average annual growth rate of $11.45 \%$. Among it, it shows a certain degree of decline from 2005 to 2009. During the period of rapid growth from 2013 to 2016 , the total passenger flow increased from 372,314 to $1,288,720$, with an average annual growth rate of $82.05 \%$.

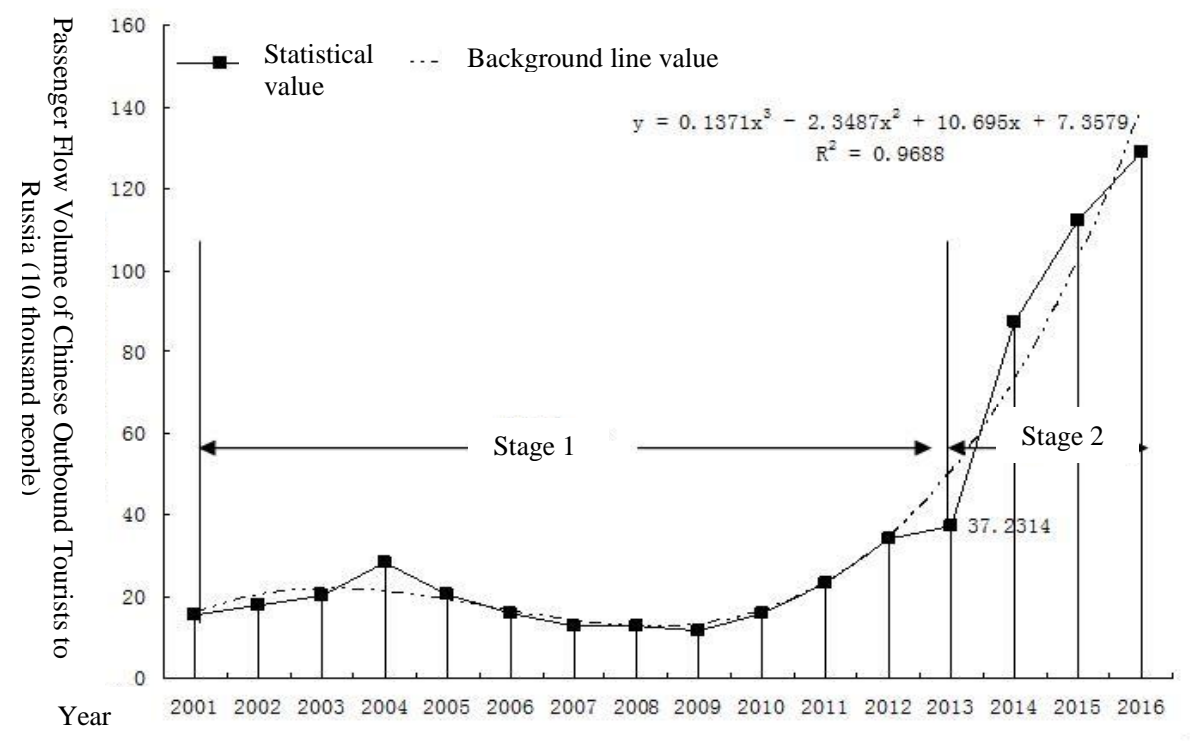

Fig. 1. Background trend line of passenger flow volume of China's Outbound Visitor to Russia (2001-2016).

\section{B. The Impact of Major Events on Passenger Flow Volume of China's Outbound Tourist to Russia}

The arrows refer to the impact of major events on China's outbound tourist flow to Russia including the "China Week" held in St. Petersburg, Russia in 2003, the opening of the third International Tourism Festival in the China-RussiaMongolia border region in Chita, Russia in 2004, and the China-Russia Expo in Harbin in 2014 respectively. The "convex peak" above the arrow is the increment in passenger flow volume caused by major tourism events. Based on the theory of natural trend curve, this study establishes the background trend line equation of passenger flow volume of Chinese outbound tourists to Russia:

$$
\begin{aligned}
& y=0.1371 \times 3-2.3487 x 2+10.695 x+7.3579(\text { Formula } 1) \\
& R 2=0.9688
\end{aligned}
$$

Among them, Formula 1 is the background trend line equation of passenger flow volume of China outbound to Russian. The equation is a cubic function, and the degree of fitting is as high as 0.9688 . Among them, $\mathrm{X}$ is $1,2,3,4, \ldots$, and $\mathrm{Y}$ is the passenger flow volume. According to the formula: increment of tourists $=$ tourist statistics background trend value; (contribution of tourists = increase / background trend value) $* 100 \%$, the impact of the event on the inbound tourist flow in China is analyzed and evaluated. 


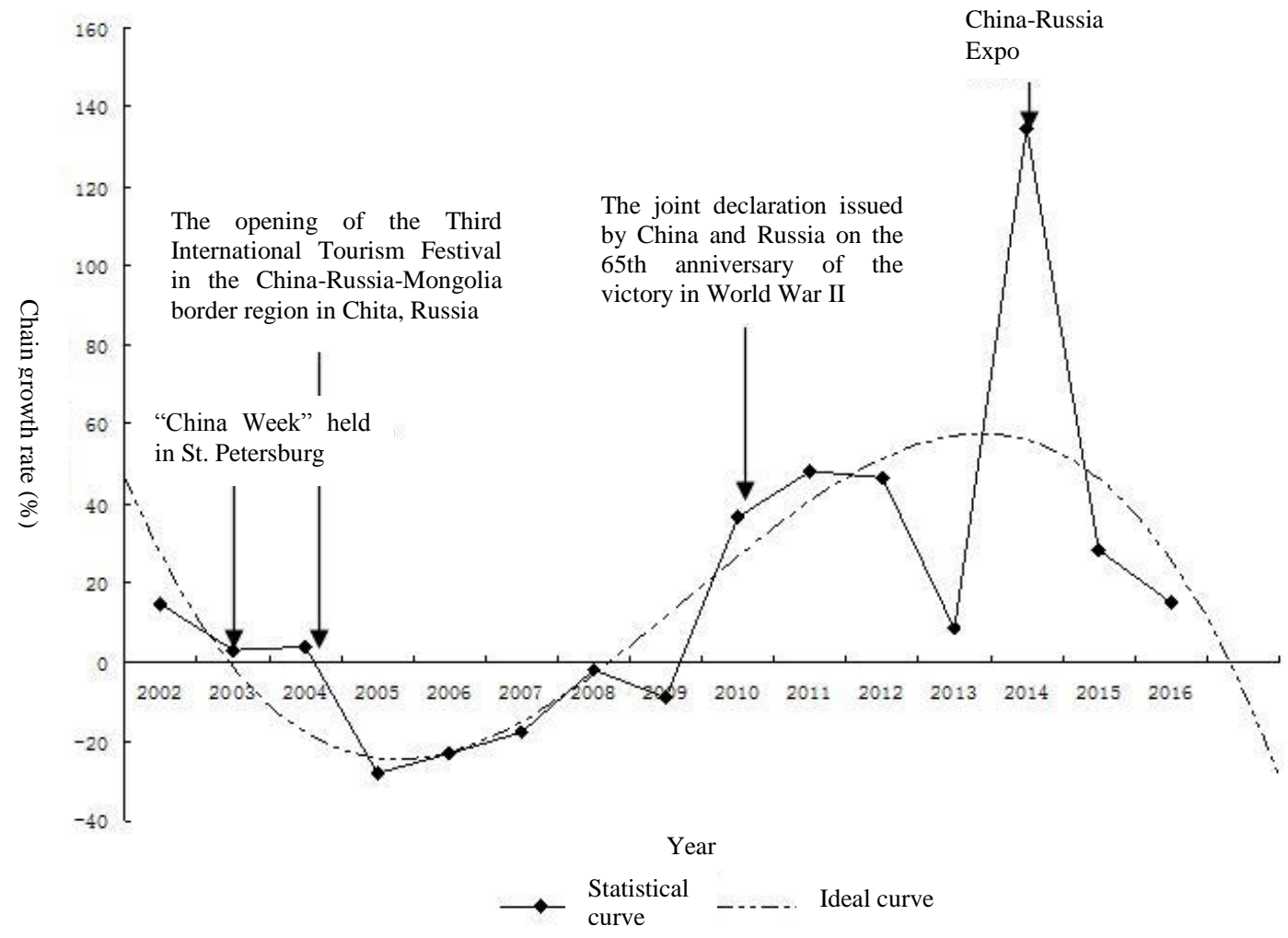

Fig. 2. Change in chain growth rate of outbound Russian passenger flow in China.

The interaction of tourism flows between the two countries should be significantly affected by the SinoRussian relations and major political policy events. The results of using the background trend line theory to quantify the impact of major tourist events in Sino-Russian relations on passenger flow are as follows. In 2004 and 2005, the statistics on the number of Chinese outbound Russian tourists is higher than the background value. In 2004, the International Tourism Festival held at the border of China, Russia, and Mongolia was opened in Chita, Russia, and the passenger flow volume from China to Russia was affected. The impact of the incident on the passenger flow volume continued for 1 year until the number of people returned to the background value in 2006. The Chinese outbound tourists to Russian increased by approximately 50,000 people, with an average contribution rate of $25 \%$. In 2014 , the China-Russia Expo was held and the impact of the event on passenger flow volume lasted for 2 years and the average contribution rate was $60.22 \%$

The chain growth rate is an important index of the rate of tourism development. "Fig. 2" shows the chain growth rate of tourist flow volume of Chinese outbound tourists to Russia during 2001-2016. Among them, the dotted full line is the statistical value of the chain growth rate, and the dotted line in the shape of zigzag fluctuation is the ideal curve added by the author, which reflects the ideal state of chain growth rate of China outbound tourism to Russian. Taking the ideal curve as a reference system, it can be seen from "Fig. 2" that from 2001 to 2016, the chain growth rate curve of China outbound tourist flow in Russia formed three “convex peaks". Among them, the China-Russia Expo held in 2014 had the greatest impact on changes in passenger flow volume. The chain growth rate increased 80 percentage points over the previous year. In 2010, the joint declaration issued by China and Russia on the 65th anniversary of the victory in World War II had a significant impact on the passenger flow volume of China outbound tourists Russian. The year-on-year growth rate has increased by 10 percentage points in this year. In 2004, the international tourism festival among China, Russia, and Mongolia also had a great impact. The duration lasted for one year, and the chain growth rate in the year was up by 25 percentage points. 
C. The Correlation between Chinese Outbound Passenger

Flow Volume to Russian and Import and Export of Service Trade in China

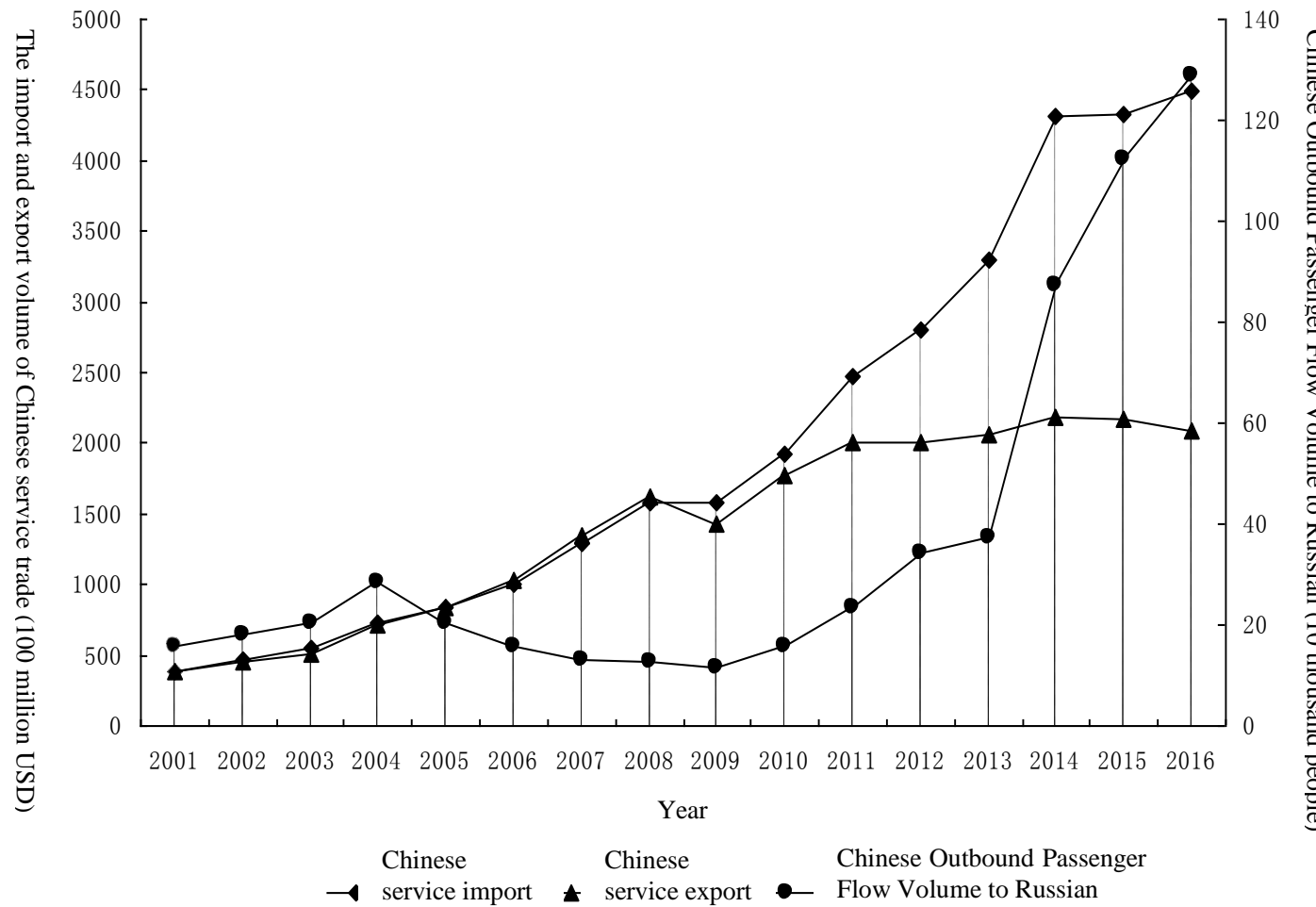

Fig. 3. The passenger flow volume of Chinese outbound tourists to Russia and Import and Export of Service Trade in China.

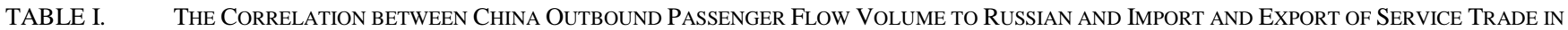
CHINA

\begin{tabular}{|c|c|c|c|c|}
\hline & & $\begin{array}{c}\text { Chinese Outbound Passenger } \\
\text { Flow Volume to Russian }\end{array}$ & $\begin{array}{c}\text { Chinese service } \\
\text { import }\end{array}$ & $\begin{array}{c}\text { Chinese service } \\
\text { export }\end{array}$ \\
\hline $\begin{array}{l}\text { Chinese Outbound Passenger } \\
\text { Flow Volume to Russian }\end{array}$ & $\begin{array}{l}\text { Pearson correlation } \\
\text { significance (two-tailed) } \\
\mathrm{N}\end{array}$ & $\begin{array}{l}1 \\
16\end{array}$ & $\begin{array}{l}.851 * * \\
.000 \\
16\end{array}$ & $\begin{array}{l}.576 \\
.019 \\
16\end{array}$ \\
\hline Chinese service import & $\begin{array}{l}\text { Pearson correlation } \\
\text { significance (two-tailed) } \\
\mathrm{N}\end{array}$ & $\begin{array}{l}.851 * * \\
.000 \\
16\end{array}$ & $\begin{array}{l}1 \\
16\end{array}$ & $\begin{array}{l}.906 * * \\
.000 \\
16\end{array}$ \\
\hline Chinese service export & $\begin{array}{l}\text { Pearson correlation } \\
\text { significance (two-tailed) } \\
\mathrm{N}\end{array}$ & $\begin{array}{l}.576^{*} \\
.019 \\
16\end{array}$ & $\begin{array}{l}.906 * * \\
.000 \\
16\end{array}$ & $\begin{array}{l}1 \\
16\end{array}$ \\
\hline
\end{tabular}

- Theoretical level: P values of service export value and import value of China are all less than 0.05, indicating that this value is significantly related to Russia outbound passenger flow to mainland China. Compared with the absolute value of $\mathrm{R}$, it is found that the correlation between China's service trade import volume and passenger flow is stronger than export volume.

- Statistics level: Based on the statistical data, "Fig. 3" and "Table I" show that overall the change in China's exports to Russia and the change in the value of China's trade in services have risen and fall together, indicating that the increase or decrease in the number of tourists is consistent with the changes in the national economy. From 2001 to 2009, the change can be divided into two phases. From 2001 to 2009, China's service trade imports and exports were basically the same. The number of Chinese outbound tourists to Russia rose from 156,792 to 15.810 million. China exports of service trade rose steadily to 177.4 billion U.S. dollars from 38.7 billion U.S. dollars, and China's service trade imports steadily increased from 39 billion U.S. dollars to 192.3 billion U.S. dollars. From 2010 to 2016, imports grew faster than exports, and imports were higher than exports. The number of 
Chinese outbound tourists to Russia rose from 158,016 to $1,280,720$. China service trade exports increased from US\$177.4 billion to US\$208.3 billion, and China's service trade imports increased from US $\$ 192.3$ billion to US\$449.2 billion.

- Conclusion: China has a deficit in service trade. The main reason is that the development of Sino-Russia service trade lags behind and the structure is not reasonable. At present, the service trade area of the two countries is mainly concentrated in traditional industries and sectors such as tourism, transportation, and construction. Cooperation between technologyintensive and knowledge-intensive industries such as finance, insurance, communications, and consulting between China and Russia is at a preliminary stage of development. The transportation industry is a traditional item of service trade in China. It accounts for a large proportion of the import and export of service trade, but it is in a deficit state all year round. It is the item that has the largest deficit in service trade. Tourism is a traditional advantageous industry for service trade in China, and it is one of the few industries that have trade surplus with Russia. However, the problems in the tourism market in China and Russia are also obvious: complicated visa procedures, misunderstanding caused by cultural differences between China and Russia, and the negative impact of the uncivilized behavior of these tourists and the monotony and low quality of tourism products still plague the benign development of the tourism market. Sino-Russian trade in services is unevenly distributed among industries. China's exports to Russia are mainly concentrated in traditional service industries such as tourism, transportation, and construction while imports are much wider. Apart from the traditional service industries, the service industries centered on the hightech such as computer and information services, using fee for proprietary right, and license fee, and finance have become the boosters of China-Russia service trade. Russia's technology-intensive and knowledgeintensive service industries have developed rapidly, and there has been an obvious trend towards technology and knowledge-intensive changes in China's service trade export structure. Therefore, in order to change its service trade deficits, China needs to start from two aspects. First is to improve the above problems in China-Russia tourism, and make the development of tourism surplus bigger and stronger. Second, it must also strengthen the improvement of its own technical level and financial sector.

\section{RUSSIAN OUTBOUND TOURISM TO CHINA}

\section{A. Changes in Russian Outbound Passenger Flow Volume to China}

The growth of passenger flow volume is the first indicator of tourism development. "Fig. 4" is the background trend line of passenger flow volume of Russian outbound tourists to China from 2001 to 2016, showing the trend of quadratic function. Among them, the dotted full line is the statistics line of passenger flow volume, and the dotted line is the travel background trend line. The overall passenger flow volume of Russian outbound tourists to China mainland has shown an upward trend. The total amount has increased from 1,196,200 in 2001 to 1,977,000 in 2016, an increase of 1.65 times. It can be broadly divided into two phases: rapid growth phase and slow decline phase: from 2001 to 2008, it is the period of rapid growth. The total passenger flow volume has rapidly increased from $1,196,200$ to $3,123,400$, with an average annual growth rate of $161 \%$. Since 2008, it has shown a slow decline. The total number of passengers has decreased from $3,123,400$ to 197,700 , with an average annual growth rate of $-36.7 \%$. 


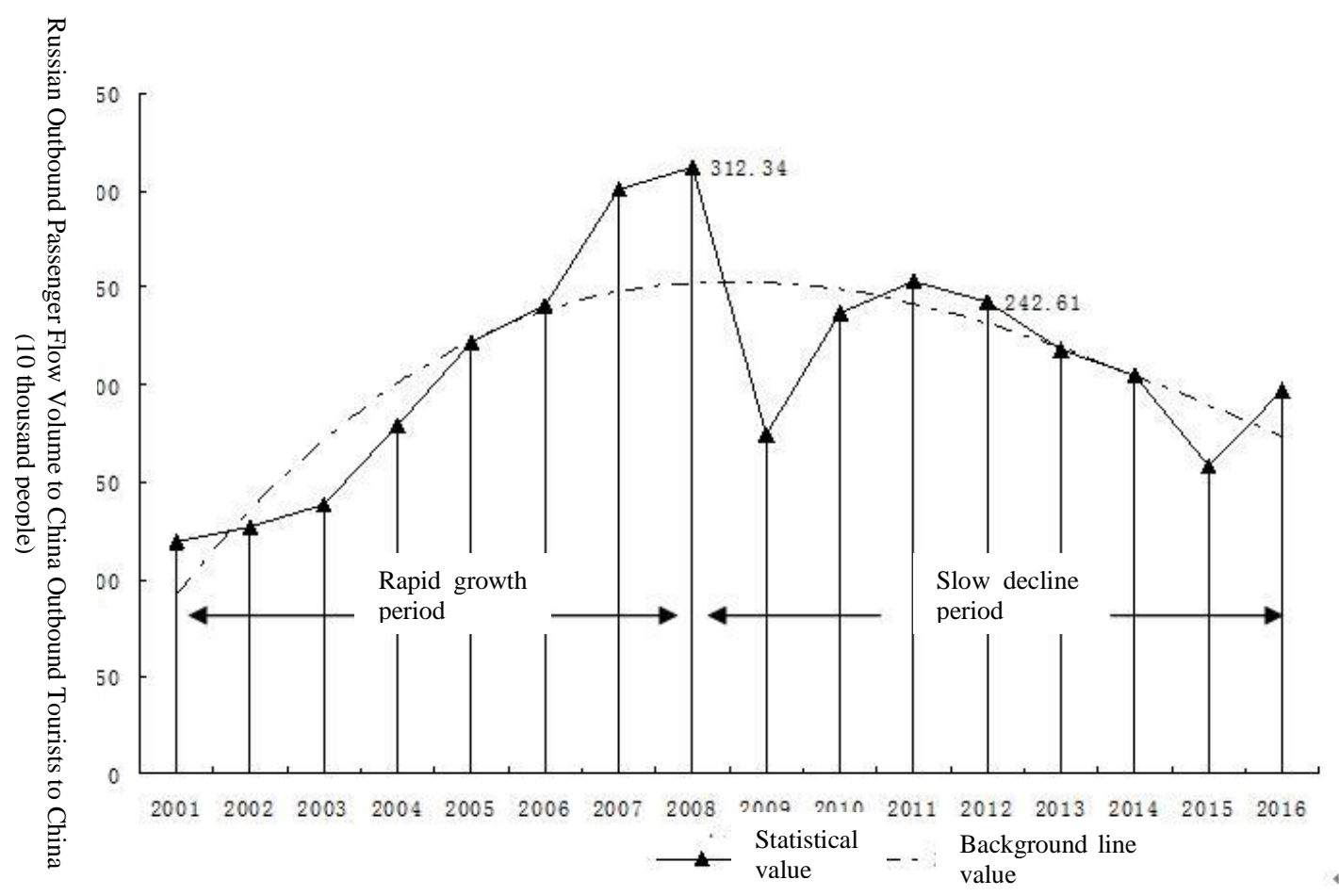

Fig. 4. Background trend line of passenger flow volume of Russia Outbound Visitor to China (2001-2016).

\section{B. The Impact of Major Events on the Passenger Flow Volume of Russian Outbound Tourists to China}

The arrows refer to the impact of major tourist events such as the "China Tourism Year" held in Russia in 2006, the 60th anniversary of the establishment of diplomatic ties between China and Russia in 2009, and the "China Tourism Year" held in Russia in 2013 on the inbound passenger flow volume. The "convex peak" above the arrow is the increase in passenger flow caused by favorable events. Based on the theory of natural trend curve, this study establishes the background trend line equation of passenger flow volume of Chinese outbound tourists to Russia:

The quadratic equation: $\mathrm{y}=-2.1432 \mathrm{x} 2+40.171 \mathrm{x}+$ 66.841 (Equation 2) can be gained by using the background trend line method.

$\mathrm{R} 2=0.636$. Among them, Formula 2 is the background trend line equation of passenger flow volume of Chinese outbound tourists to Russian, and the equation is a composite of cubic functions with a fitting degree of 0.636 , which shows that the degree of equation fitting is compatible and the degree of credibility is upper middle. Among them, $\mathrm{X}$ is
$1,2,3,4, \ldots$, and $\mathrm{Y}$ is the passenger flow volume. According to the calculation formula, the increase of tourists $=$ the statistics of tourists- background trend value; (contribution of tourists=increase of tourists / background trend value)* $100 \%$, the impact of the events on the passenger flow volume of Russian outbound tourists to China is analyzed and evaluated.

As can be seen from "Fig. 5", the statistics on the number of Russian outbound tourists to China in 2007 and 2008 are higher than the background line value. In 2006 and 2007, China and Russia held tourism year mutually, and the passenger flow volume of Russian outbound tourists to China was affected. This event affects the passenger flow volume for two years until mid-2008 when the number of people returned to the background line value. Russian outbound tourists to China increased by approximately 800,000 people, with an average contribution rate of $32 \%$. In 2012, the passenger volume of Russian outbound tourists to China is higher than the background line value. In 2012, the "Russia Tourism Year" was held in China, of which the impact lasted for one year. Russia outbound passenger flow volume to China increased by about 50,000 people, with an average contribution rate of $2.1 \%$. 


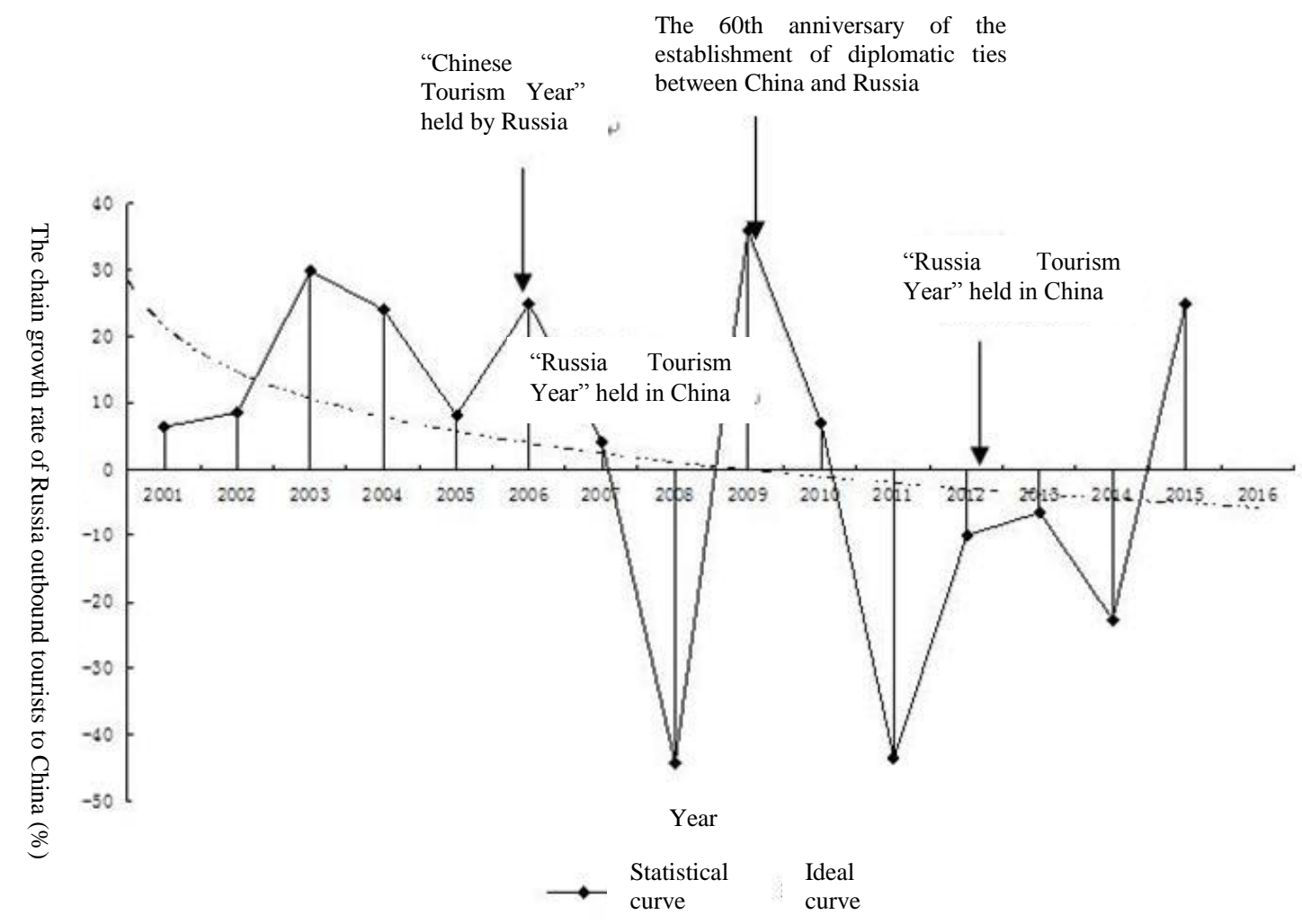

Fig. 5. Change in chain growth rate of passenger flow volume of Russian outbound tourists to China.

The chain growth rate is an important index of the rate of tourism development. Figure 5 shows the chain growth rate curve of passenger flow volume of Russian outbound tourists to China from 2001-2016. Among them, the dotted full line is the statistical value of the chain growth rate, and the dotted line in the shape of zigzag fluctuation is the ideal curve added by the author, which reflects the ideal state of chain growth rate of inbound tourism. Taking the ideal curve as a reference system, it can be seen from "Fig. 6" that from 2001 to 2016, the chain growth rate curve of Russia outbound tourist to China formed four "convex peaks". Among them, the "60th anniversary of the establishment of diplomatic relations between China and Russia" in 2009 had the greatest impact on Russia's outbound passenger flow in China, with the chain growth rate increasing 45 percentage points. The first "China Tourism Year" event organized by Russia in 2006 made the chain growth rate increase by 10 percentage points. In 2012 and 2013, the "China and Russia's second year of mutual tourism" caused the chain growth rate to increase by 5 percentage points.

\section{The Correlation between Russia Outbound Passenger Volume to China and Import and Export of Russian Service Trade}

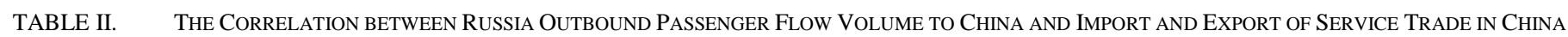

\begin{tabular}{|c|c|c|c|c|}
\hline & & $\begin{array}{l}\text { Russian Outbound Passenger } \\
\text { Flow Volume to China }\end{array}$ & $\begin{array}{c}\text { Russian service } \\
\text { import }\end{array}$ & $\begin{array}{c}\text { Russian service } \\
\text { export }\end{array}$ \\
\hline $\begin{array}{l}\text { Russian Outbound Passenger } \\
\text { Flow Volume to China }\end{array}$ & $\begin{array}{l}\text { Pearson correlation } \\
\text { significance (two-tailed) } \\
\mathrm{N}\end{array}$ & $\begin{array}{l}1 \\
16\end{array}$ & $\begin{array}{l}.425 \\
.101 \\
16 \\
\end{array}$ & $\begin{array}{l}.524^{*} \\
.037 \\
16 \\
\end{array}$ \\
\hline Russian service import & $\begin{array}{l}\text { Pearson correlation } \\
\text { significance (two-tailed) } \\
\mathrm{N}\end{array}$ & $\begin{array}{l}.425 \\
.101 \\
16\end{array}$ & $\begin{array}{l}1 \\
16 \\
\end{array}$ & $\begin{array}{l}.983^{* * *} \\
.000 \\
16\end{array}$ \\
\hline Russian service export & $\begin{array}{l}\text { Pearson correlation } \\
\text { significance (two-tailed) } \\
\mathrm{N}\end{array}$ & $\begin{array}{l}.524 * \\
.037 \\
16 \\
\end{array}$ & $\begin{array}{l}.983^{* *} \\
.000 \\
16 \\
\end{array}$ & $\begin{array}{l}1 \\
16 \\
\end{array}$ \\
\hline
\end{tabular}

b. $* *$. means it is significantly correlated at the level .01 (two-tailed) *. means it is significantly correlated at the level 0.05 (two-tailed) 


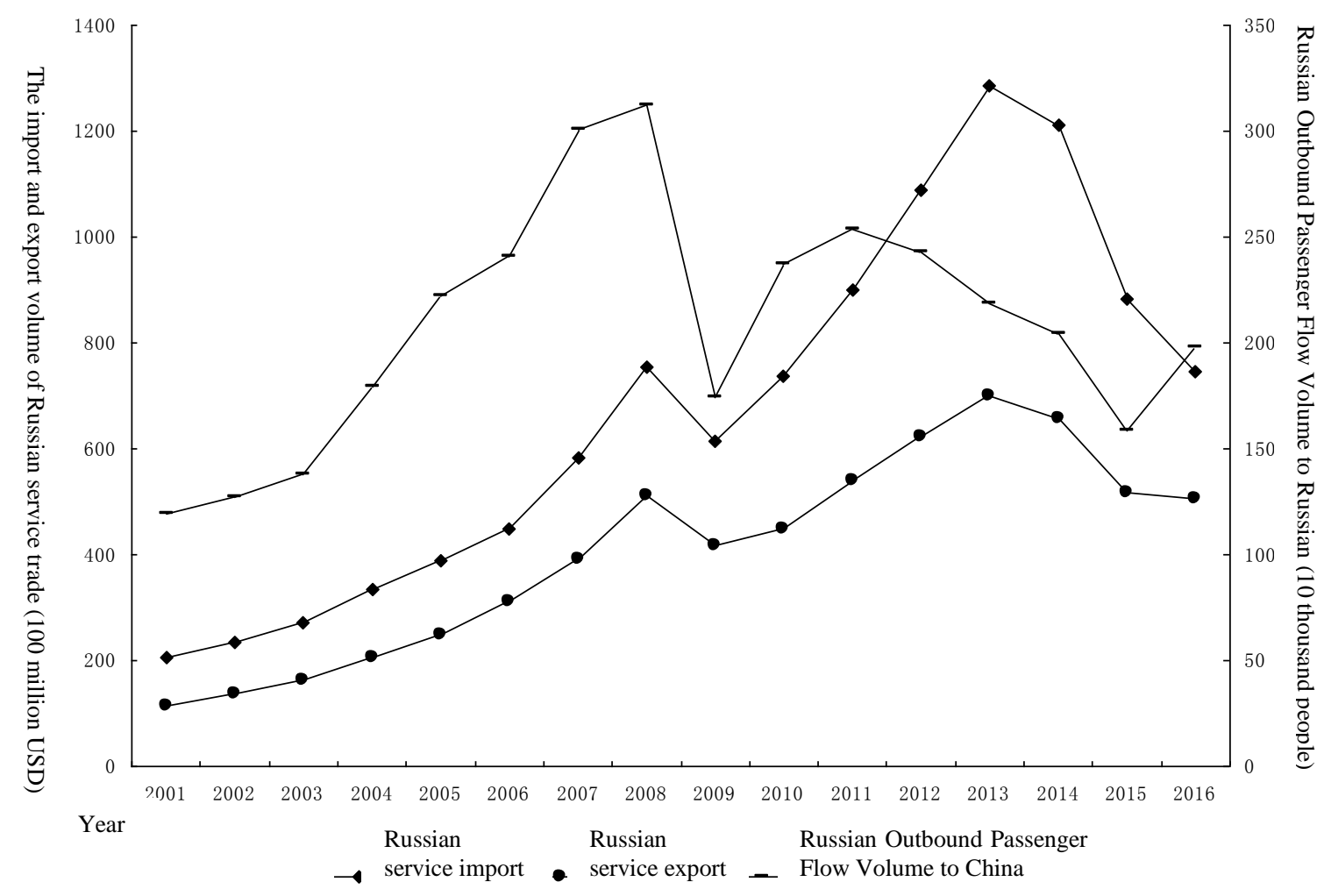

Fig. 6. The passenger flow volume of Russian outbound tourists to China and Import and Export of Service Trade in Russia.

Marco Polo hypothesis believes that: a business customer travel to a country with the purpose of selling or buying goods, which led to export trade and import trade. This article analyzes the correlation between passenger flow volume and import and export of service trade

- Theoretical level: According to "Table II", the exports of Russian service P value is less than 0.05 , which is considered statistically significant and indicates that this value is significantly positively related to Russian outbound passenger volume to mainland China, while the correlation between Russia's import value and passenger volume $\mathrm{P}=0.1>$ 0.05 , which is considered not significantly relevant.

- Statistical level: The pace of changes in Russia outbound passenger volume to China and import and export volume of Russia's service trade has basically risen and fall together, indicating that the increase or decrease in the number of tourists is related to and consistent with the national economic level. From 2001 to 2016, the overall situation was divided into two stages: From 2001 to 2008, the number of Russian outbound tourists to China rose from $1,996,200$ to $3,123,400$. The export value of Russian service trade steadily increased from 11.441 billion U.S. dollars to 51.179 billion U.S. dollars, and imports of Russia's service trade increased from $\$ 20.573$ billion to $\$ 75.468$ billion. From 2009 to 2016, the number of Russian outbound tourists to China rose from 174 million to 2.54 million. The exports of Russia's service trade increased from US\$ 41.594 billion to US\$ 69.865 billion, and the imports of Russian service trade increased from US\$ 61.429 billion to US\$ 7.46 billion. The node change in the number of import is not as synchronous as the other two lines, indicating that the number of Russian outbound tourists to China is related to the import value of Russian service trade but it is not significant.

- Summary: From both theoretical and statistical perspectives, it can be concluded that compared with the exports value of service trade, Russian outbound tourists to China is more conducive to Russia's export trade than to import trade and the change in number has less impact on import trade, which indirectly verify the correctness of Marco Polo theory.

\section{CONCLUSION}

- The overall passenger flow volume of Chinese outbound tourists to Russia is on an upward trend. The growth is divided into two phases. The first phase is 2001-2013. The second phase is from 2013 to the present. Obviously, the growth rate in the first phase is flat and the growth rate in the second phase is higher than that of the first stage. The volume of Russian outbound tourists to China as a whole shows a trend of increasing first, then decreasing, increasing, and then decreasing. The growth is divided into two 
segments. The first phase is 2001-2008, and the second phase is from 2008 to the present.

- From both theoretical and statistical perspectives, it can be concluded that compared with the value of service trade exports, Russian outbound tourists to China has a stronger driving effect on Russian export trade than import trade; compared with service trade import, the volume of Chinese outbound tourists to Russia has stronger driving effect on imports of China than exports.

- Influence of major tourism events on passenger flow volume

The passenger flow volume of Chinese outbound tourists to Russia is affected by the international tourism festival held at the border of China, Russia, and Mongolia in 2004. The impact on passenger flow volume continues for one year and the passenger flow increases by about 100,000. 2010 is the 65th anniversary of the victory of World War II. China and Russia issue a joint statement to establish a strategic partnership and leaders of the two sides make mutual visits. The incident has affected passenger traffic for two years, and passenger traffic has increased by 200,000 .

Russian outbound passenger flow to China was affected by the years of tourism exchange between China and Russia in 2006 and 2007. The impact on passenger flow continued for two years. Russia's outbound passenger flow in China increased by approximately 800,000; and Russia's Tourism Year held in China in 2012 has the impact lasting for one year and Russia's outbound tourists to China increased by about 50,000 people.

\section{REFERENCES}

[1] Wang Jiejie, Sun Gennian. The influence of international relations and major events on the inbound and outbound tourism. 王洁洁, 孙根 年. 国际关系及重大事件对出入境旅游的影响.

[2] Wang Wenyi. Prospects of Sino-Russian Tourism from Sino-Russian Political and Economic Development, Journal of Changji University, 2006,3 . 王文艺. 从中俄政治经济发展看中俄旅游前景, 昌吉学院 学报 2006 第 3 期.

[3] Cheng Bing, Zhu Jinsheng. Research on the Influencing Factors of Russian Tourists' Consumption Behavior in China. Tourism Forum, 2013: 5. 程冰, 朱锦晟. 俄罗斯来华旅游者消费行为的影响因素研 究. 旅游论坛, 2013: 5 .

[4] Song Kui, Chen Qiujie. Review and Prospect of Sino-Russia Tourism Cooperation, Siberian Studies, 2001:10. 宋鬼, 陈秋杰. 中俄旅游合作 的回顾与展望, 西伯利亚研究 2001:10.

[5] Victoria. Strategic Research on International Tourism Cooperation between China and Russia, Dongbei University Of Finance And Economics, 2014: 5. 维卡多莉亚. 中国与俄罗斯开展国际旅游合作 的策略研究, 东北财经大学, 硕士学位论文 2014: 5.

[6] Shi Zhangyu, Xu Hong, Shen Jinghong. Empirical study of the interactive relationship between bilateral tourism and import and export trade between China and Russia, Cultural Geography, 2015: 2. 石张宇, 徐 虹, 沈惊宏. 中俄双边旅游与进出口贸易互动关系的 实证研究, 人文地理 2015:第二期.

[7] Ovcharov, A.A,2008, Russian's Tourism Industry: Trends and Risks, problems Of Economic Transition,51(5),PP56-67

[8] Burns,P., 1998. Tourism in Russia: background and structure,Tourism Management,Vol.19,PP555 565. 